\title{
Rancang Bangun Sistem Administrasi Kependudukan Kantor Kepala Desa Sukamerta Berbasis Dekstop
}

\author{
${ }^{1}$ Ami Natuzzuhriyyah, ${ }^{2}$ Rini Mayasari \\ ${ }_{1,2}^{1}$ Universitas Singaperbangsa Karawang
}

\author{
Alamat Surat \\ Email: ami.natuzzuhriyyah17051@student.unsika.ac.id
}

Article History:

Diajukan: 30-03-2021; Direvisi: 14-04-2021; Diterima: 28-04-2021

\begin{abstract}
ABSTRAK
Penelitian yang dilakukan di Desa Sukamerta ini dengan mencoba membuat sebuah rancangan sistem administrasi kependudukan guna menunjang aktivitas kegiatan istansi pemerintahan dengan menggunakan bahasa pemrograman java. Untuk metode pengembangan software yang akan dilakukan mengguankan metode Systems Development Life Cycle (SDLC). Dengan pembuatan sistem administrasi kependudukan ini diharapkan dapat mempermdah dan efisiensi waktu untuk staff untuk melakukan pelayanan administrasi kependudukan pada warga Desa Sukamerta serta mempermudah melakukan laporan untuk pendataan penduduk. Selama staff desa Sukamerta melakukan pelayanan administrasi kependudukan yang beberapa masih dilakukan secara konvensional dimana staff harus mencatat data pemohon pada pembuatan surat pengantar Kartu Keluarga (KK) maupun Kartu Tanda Penduduk (KTP). Oleh karena itu, dibutuhkan sistem administrasi kependudukan yang memudahkan dan mempercepat kinerja staff desa. Rancang bangun sistem yang akan dibuat menggunakan tools netbeans 8.2 dengan menggunakan metodelogi SDLC dengan pemodelan atau desain dari UML yaitu menggunakan usecase diagram, activity diagram dan sequence diagram. Hasil yang didapatkan berupa sistem administrasi kependudukan berbasis desktop yang akan membantu pembuatan surat-surat yang dibutuhkan warga serta pendataan penduduk untuk mempermudah staff dalam membuat laporan akhir kependudukan.
\end{abstract}

Kata Kunci: Administrasi kependudukan; Systems Development Life Cycle (SDLC); Unified Modeling Language (UML)

\section{ABSTRACT}

This research was conducted in Sukamerta Village by trying to make a population administration system design to support the activities of government agencies using the Java programming language. For software development methods that will be carried out using the Systems Development Life Cycle (SDLC) method. With the creation of this population administration system, it is hoped that the staff will be able to simplify and efficiently perform population administration services for residents of Sukamerta Village and make it easier to carry out reports for population data collection. As long as the Sukamerta village staff perform population administration services which are carried out conventionally where the staff must record the applicant's data in making cover letters for the Family Card (KK) and Identity Card $(K T P)$. Therefore, a population administration system is needed that will facilitate and accelerate the performance of village staff. System design that will be made using Netbeans 
8.2 tools using SDLC methodology with UML modeling or design, namely using usecase diagrams, activity diagrams and sequence diagrams. The results obtained are in the form of a desktop-based population administration system that will assist in making the letters needed by residents as well as population data collection to facilitate staff in making final population reports.

\section{Keywords: Population Administration; Systems Development Life Cycle (SDLC); Unified Modeling Language (UML)}

\section{PENDAHULUAN}

Kantor Desa Sukamerta yaitu salah satu instansi pemerintahan yang berada di kabupaten Karawang dengan mempunyai kewajiban yaitu melayani administrasi kependudukan sebagai bentuk pelayanan kepada masyarakat seperti pembuatan surat pengantar Kartu Keluarga (KK), Kartu Tanda Penduduk (KTP) dan surat-surat yang disediakan. Dalam perundang-undangan Indonesia, Administrasi Kependudukan diatur di dalam Undang-Undang Republik Indonesia Nomor 23 Tahun 2006 Tentang Administrasi Kependudukan:" Administrasi kependudukan adalah rangkaian kegiatan penataan dan penerbitan dokumen dan data kependudukan melalui program pendaftaran penduduk, pencatatan sipil, pengelolaan informasi administrasi kependudukan serta pendayagunaan hasilnya untuk pelayanan publik dan pembangunan sektor lain". Adapun bentuk-bentuk dari dokumen kependudukan tersebut, pada intinya meliputi antara lain Nomor Induk Kependudukan (NIK), Kartu Keluarga (KK), Kartu Tanda Penduduk (KTP), Akta/Surat Nikah/Cerai, Akta Kelahiran/Kematian, Akta Pengesahan Anak, Pengangkatan Anak, Perubahan Nama dan Perubahan Status Kewarganegaraan

Pelayanan administrasi kependudukan yang disediakan oleh Desa Sukamerta seperti pembuatan surat pengantar Kartu Keluarga (KK), Kartu Tanda Penduduk (KTP), surat-surat lainnya yang disediakan oleh kantor desa ini masih bersifat konvensional dan pendataan penduduk seperti : pencatatan data kelahiran, data kematian, data kepindahan dan data kedatangan, penyimpanannya masih dalam buku arsip sehingga menumpuk dan sulit dalam pencarian data (Wisti, 2018) serta masih berupa papan mading.

Selama staff desa Sukamerta melakukan pelayanan administrasi kependudukan yang beberapa masih dilakukan secara konvensional dimana staff harus mencatat data pemohon pada pembuatan surat pengantar Kartu Keluarga (KK) maupun Kartu Tanda Penduduk (KTP), sedangkan untuk surat-surat masih menggunakan Microsoft Word yang berakibat format surat menjadi berubah-ubah. Oleh karena itu, dibutuhkan sistem administrasi kependudukan yang memudahkan dan mempercepat kinerja staff desa ini penting adanya dalam pembuatan suratsurat yang dibutuhkan masyarakat, karena pembuatan beberapa surat yang masih dilakukan secara manual atau dengan tulisan tangan yang belum tentu ketika surat itu diberikan kepada pihak kecamatan dapat dimengerti tulisan dari staff desa yang menulis surat-surat tersebut. Jika pembuatan sistem ini dibuat maka mempermudah staff desa dalam pembuatan surat-surat yang diperlukan oleh masyarakat/warga yang nantinya akan diberikan kepada staff kecamatan.

Pada penelitian sebelumnya mebahas mengenai rancang bangun sistem informasi data kependudukan desa berbasis desktop dan android dengan menggunakan tools netbeans 8.2 dan android stuio dengan menggunakan database MySQL hasi yang didapatkan pada aplikasi yang telah dibuat untuk memudahkan dalam pencarian informasi data penduduk. Selain itu, aplikasi ini dapat membantu instansi pemerintah desa dalam memonitoring perkembangan penduduk dan menyelesaikan kendala-kendala yang ada sehingga pelayanan kepada masyarakat bisa lebih baik dan lebih optimal (Roikhatul et al., 2019). Pada penelitian lainnya membahas mengenai Rancang Bangun Sistem Informasi di Desa Sumbermulyo Kecamatan Jogoroto Kabupaten Jombang dengan menggunakan Microsoft Visual Basic.Net 2008 dan sistem 
manajemen basis data MySQL untuk pengolahan datanya. Hasil yang didapatkan yaitu dari hasil penelitian, Desa Sumbermulyo membutuhkan sistem informasi untuk mempermudah pengolahan data kependudukan (Mohaman et al., 2016).

Pembuatan sistem administrasi kependudukan berbasis dekstop ini memanfaatkan teknologi yang akan membantu pembuatan surat-surat yang dibutuhkan warga serta pendataan penduduk untuk mempermudah staff dalam membuat laporan akhir kependudukan seperti yang dikatakan oleh bapak abdul rohman di Desa Sukamerta , Abdul rohman (2020) "membuat sebuah sistem untuk pembuatan surat keterangan dan data kependudukan agar lebih efektif dan efisien".

\section{TELAAH PUSTAKA}

Pelayanan Publik merupakan keperluan orang atau masyarakat yang mempunyai kepentingan pada organisasi tertentu sesuai dengan aturan pokok dan tata cara yang telah ditetapkan oleh organisasi atau instansi tertentu. Pemerintahan pada hakekatnya adalah pelayanan kepada masyarakat, Tidak dapat untuk melayani dirinya sendiri, tetapi untuk melayani masyarakat serta menciptakan kondisi yang memungkinkan setiap anggota masyaraakat mengembangkan kemampuan dan kreativitasnya demi mencapai tujuan Bersama (Robi, 2016).

Menurut staff kantor kepala desa sukamerta ini mempunyai banyak informasi publik mengenai kegiatan desa, informasi tidak langsung contohnya seperti melalui mading yang dimana informasi yang disediakan yang bersifat umun atau general, selain itu pelayanan publik yang disajikan dengan memberikan informasi secara langsung atau mejawab hal yang dibutuhkan oleh masyarakat secara individual atau kelompok. Contohya seperti Pembuatan Surat Pengantar kartu keluarga (KK) yang dimana salah satu staff desa akan memberikan informasi secara langsung persyaratan apasaja yang harus dibawa.

1. Jenis-jenis Pelayanan Masyarakat di Kantor Kepala Desa

Pelayananan publik yang dilakukan oleh pemerintah Desa Sukamerta merupakan bentuk pengabdian kepada masyarakat. Untuk pelayanan publik yang disediakan oleh Kantor Kepala Desa Sukamerta ini yaitu :

A. Pembuatan Surat Pengantar Kartu Keluarga (KK)

Kartu Keluarga (KK) adalah kartu identitas keluarga yang memuat data tentang susunan, hubungan dan jumlah anggota keluarga. Dan kartu keluarga ini wajib dimiliki oleh setiap keluarga yang berisika data lengkat atau identitas dari kepala keluarga sampai dengan anggota keluarga. Untuk Pembuatan Surat Pengantar Kartu Keluarga (KK) harus melengkapi syarat-syarat sebagai berikut :

1) Rusak/ Pemula/ Misah

a. Surat Pengantar dari RT/RW

b. Mengisi formlulir F1.06 yang di tandatangani oleh pemohon dan ditandatangani dan di stempel oleh RT, Kepala Desa dan camat setempat

c. Fotocopy ijazah pendidikan terakhir yang sudah dilegalisir

d. Fotocopy KK asli pemohon di database

e. Pemohon dtag sendiri atau mewakili

2) Perubahan Data

a. Surat pengantar dari RT/RW setempat

b. Mengisi formulir F1.06 yang tandatangani oleh pemohon dan ditandatangani dan di stempel oleh RT, Kepala Desa dan camat setempat

c. Lampiran KK Asli

d. Lampiran perubahan data yang benar dengan kekuatan hukum yang kuat seperti Ijazah, akta kelahiraan/ surat nikah. 
Setelah persyaratan diatas terpenuhi warga bisa datang langsung ke kantor kepala desa, kemudian staff akan menuliskan identitas dari masing-masing anggota pada Lampiran 2.1. Setelah selesai menuliskan identitas-identitas, warga bisa langsung datang ke kecamatan untuk tahap selanjutnya yang bisa langsung dilakukan.

B. Pembuatan Surat Pengantar Kartu Tanda Penduduk (KTP)

Berdasarkan Undang-undang Nomor 23 tahun 2006 tentang administraasi kependudukan, Kartu Tanda Penduduk, selanjutnya disingkat KTP, adalah identitas resmi penduduk sebagai bukti diri yag diterbitkan oleh instansi pelaksana yang berlaku di seluruh wilayah Negara Kesatuan Republik Indonesia. Oleh karena itu KTP adalah identitas resmi seorang penduduk yang harus dimiliki oleh setiap warga negara. Untuk Pembuatan Surat Pengantar KTP persyaratan yang harus dipenuhi yaitu dengan membawa :

1) KTP bukan pendatang

a. Telah berusia 17 tahun

b. Fotocopy Kartu Keluarga (KK)

c. Fotocopy akta kelahiran

2) KTP pendatang
a. Telah berusia 17 tahun
b. Fotocopy Kartu Keluarga (KK)
c. Fotocopy akta kelahiran
d. Surat Keterangan kepindahan/kedatangan

Sama halnya dengan Pembuatan Surat Pengantar Kartu Keluarga (KK), setelah persyaratan diatas terpenuhi warga bisa datang langsung ke kantor kepala desa, kemudian staff akan menuliskan identitas dari masing-masing anggota pada Lampiram 2.2 . Setelah selesai menuliskan identitas-identitas, warga bisa langsung datang ke kecamatan untuk tahap selanjutnya yang bisa langsung dilakukan.

C. Pembuatan Surat-surat

Surat yaitu sarana komunikasi secara tertulis untuk menyampaikan sebuah pesan oleh suatu pihak kepada pihak lainnya yang membutuhkan/menerima surat tersebut. Untuk menjalankan sebuah pelayanan kepada masyarakat pemerintah desa wajib mempunyai format-format dinas yang nantinya akan dibutuhkan oleh masyarakat. Untuk setiap desa mempunyai format tersendiri untuk membuat surat-surat, tidak terkecuali Desa Sukamerta yang menyediakan Surat Keterangan, Surat Keterangan Desa, Surat Domisili, Surat Keluar, Surat Masuk, Surat Pemberitahuan Kegiatan di Daerah, Surat Keterangan Nikah maupun Belum Nikah dan surat-surat lainnya. Berikut adalah gambar dari salah satu surat yang ada di Kantor Kepala Desa Sukamerta.

D. Dan Pelayanan Lainnya yang disediakan oleh Kantor Kepala Desa Sukamerta

\section{METODE PENELITIAN}

Metode Penelitian yang digunakan yaitu Systems Development Life Cycle (SDLC) yaitu metodologi umum dalam pengembangan sistem yang menandai kemajuan usaha analisis dan desain. Tahapan pada metodologi ini yaitu:

1) Perencanaan Sistem (Systems Planning)

2) Analisis Sistem (Systems Analysis)

3) Perancangan Sistem (Systems Design)

4) Implementasi Sistem (Systems Implementation)

5) Pemeliharaan Sistem (Systems Maintenance) (Weiskhy et al., 2018). 
Dengan menggunakan pemodelan atau desain UML Dalam tahap ini, desain sesuai kebutuhan sistem akan dibuat terkait rancangan sistem administrasi kependudukan yang akan dibuat. Penggunaan Unified Modeling Language (UML) dimaksud menjelaskan lebih terperinci. UML yang akan digunakan adalah usecase diagram, acticity diagram dan sequence diagram.

\section{HASIL DAN PEMBAHASAN}

Berdasarkan permasalahan pada penempatan kerja yaitu pada kasi pemerintahan yang dimana penulis memberikan rekomendasi untuk permasalahan dalam penulisan surat pengantar Kartu Keluarga (KK), surat pengantar Kartu Tanda Penduduk (KTP), yang dilakukan secara manual, surat pengantar yang tidak tersusun dengan rapi dan banyak yang tidak bisa dibuka dan data kependudukan yang masih ditulis dimading untuk dijadikan pertimbangan oleh Kepala Desa Sukamerta dengan menggunakan uml sebagai pemodelan, diantaranya :

A. Usecase diagram

Usecase diagram yaitu gambaran singkat mengenai hubungan actor dan system secara grapichal. Berdasarkan usecase diagram yang dibuat actor "Staff Desa" memiliki tugas atau hak akses untuk:

1) Login

Staff desa dapat mengakses system dengan memasukkan username dan password yang sudah dibuat pada database atau manual.

2) Membuat Surat Pengantar KK

Staff Desa dapat membuat, menambahkan, mengedit, melihat dan menghapus data pada surat pengantar yang aka dibuat.

3) Membuat Surat Pengantar KTP

Staff Desa dapat membuat, mengedit, melihat dan menghapus data pada surat pengantar yang aka dibuat.

4) Membuat atau Mengelola Data Kependudukan

Staff Desa dapat membuat, mengedit, melihat, menghapus data atau mengambil data pada surat pengantar KK dan KTP untuk surat pengantar yang aka dibuat.

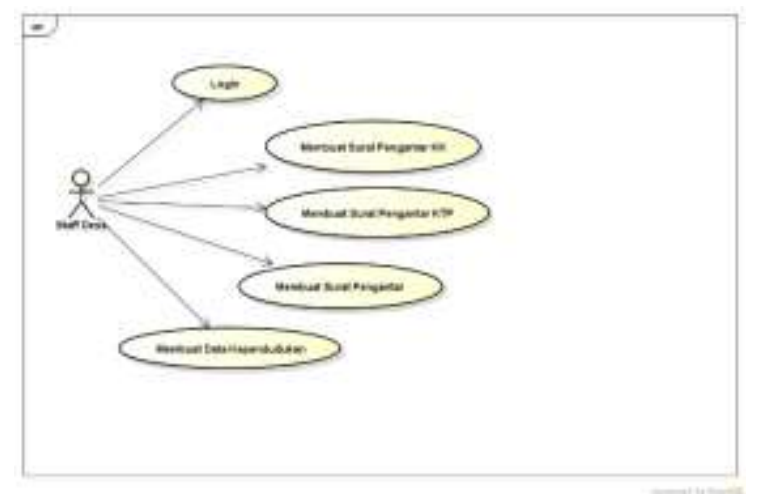

Gambar 1. Usecase Diagram

B. Activity Diagram

Penggambaran aktivitas yang dapat dilakukan sisem, diagaram ini menunjukan Langkah-langkah berjalannya system yang akan dibuat

1) Surat Pengantar KK 


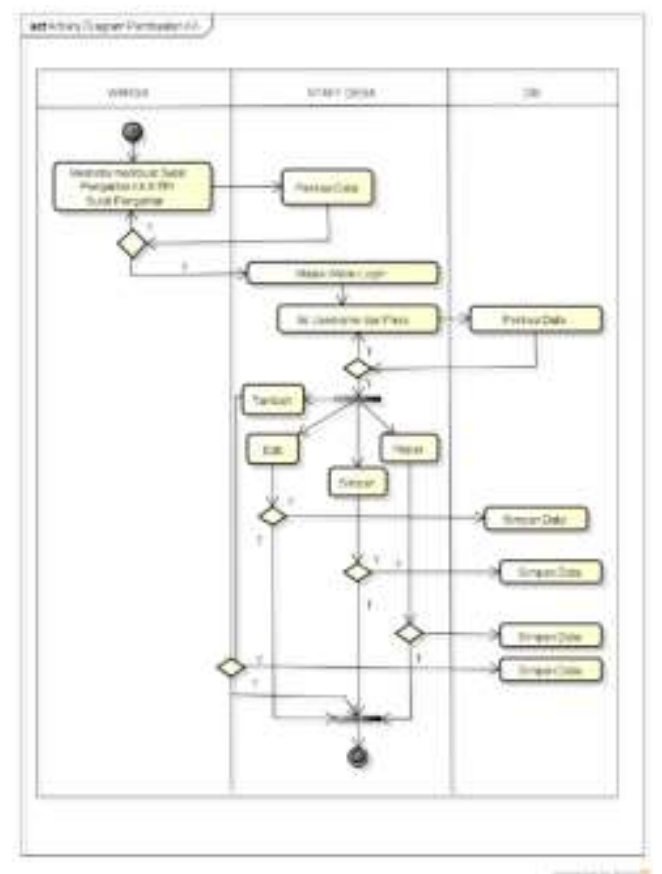

Gambar 2. Activity Diagram Kartu Keluarga(KK)

2) Surat Pengantar dan KTP

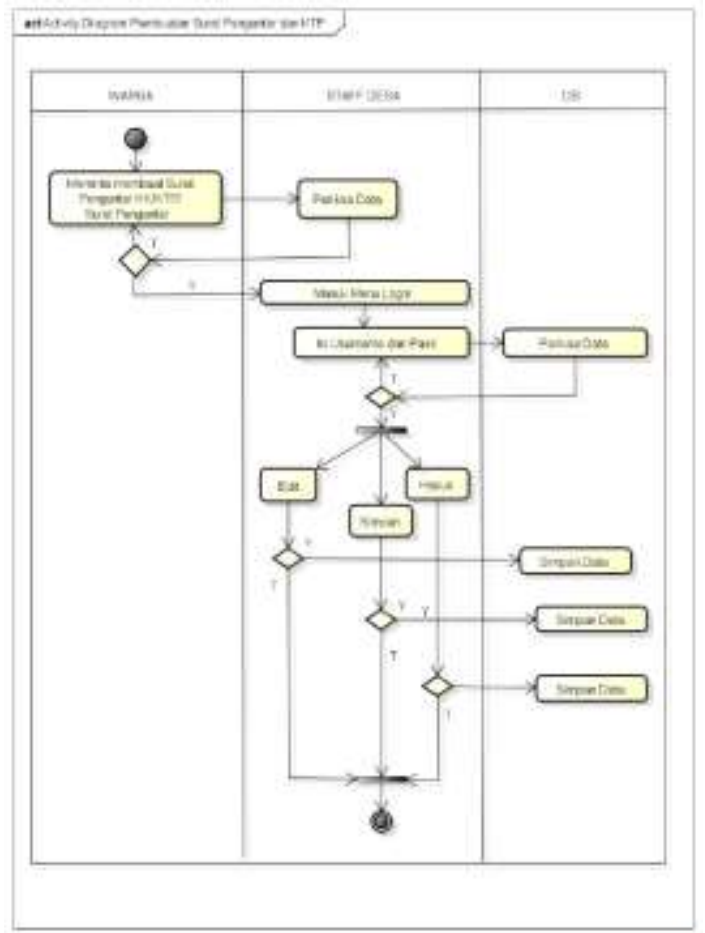

Gambar 3. Activity Diagram KTP 
3) Data Kependudukan Desa

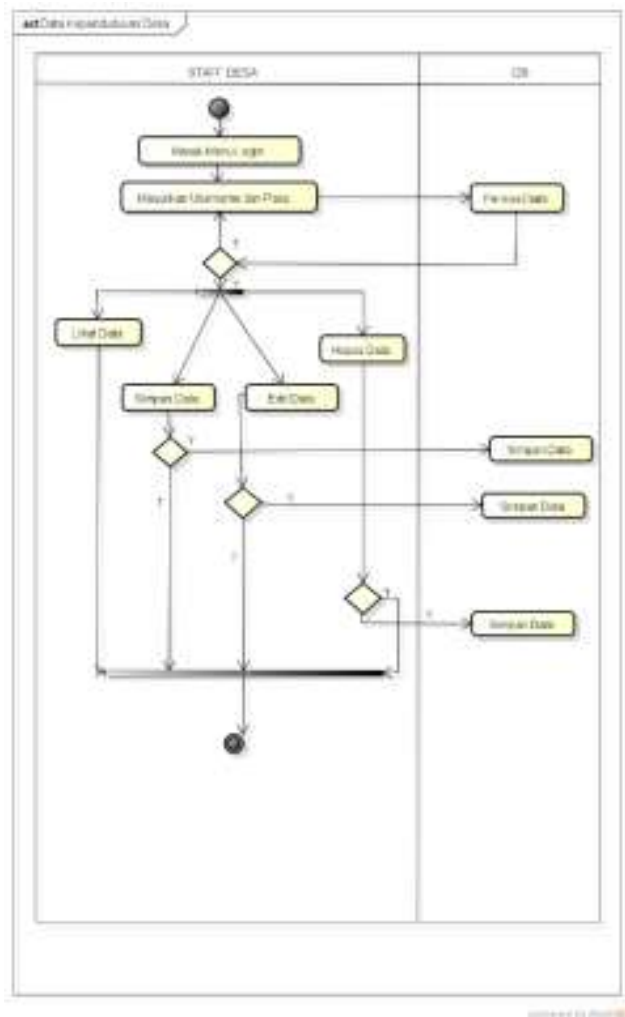

Gambar 4. Activity Diagram Data Kependudukan

\section{Sequence Diagram}

Diargram yang menggambarkan kolaborasi dinamis antara antara sejumlah objek guna menunjukan rangkaian pesan yang dikirim antara objek

1) Surat Pengantar, KK dan KTP

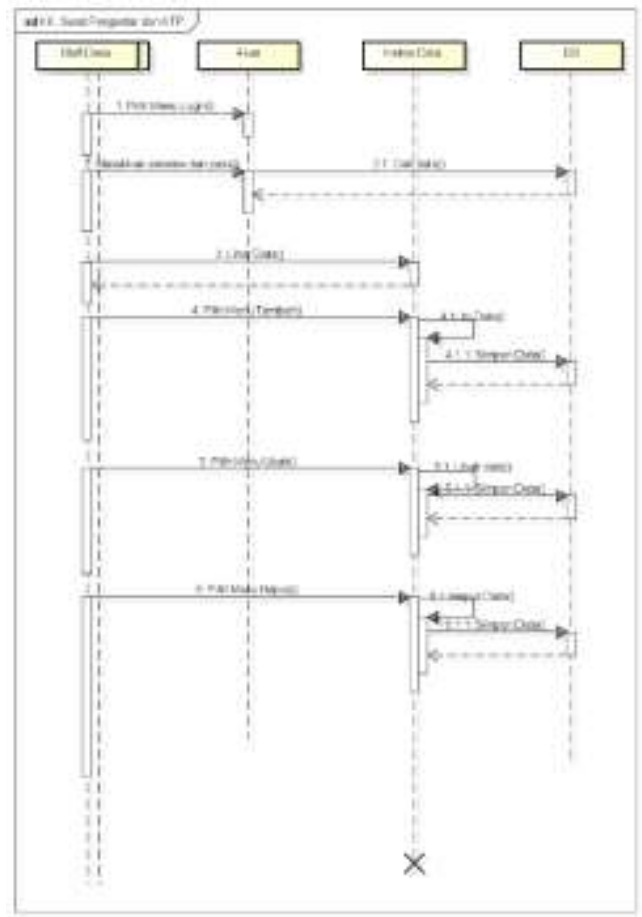

Gambar 5. Sequence Diagram KK \& KTP 
2) Data Kependudukan

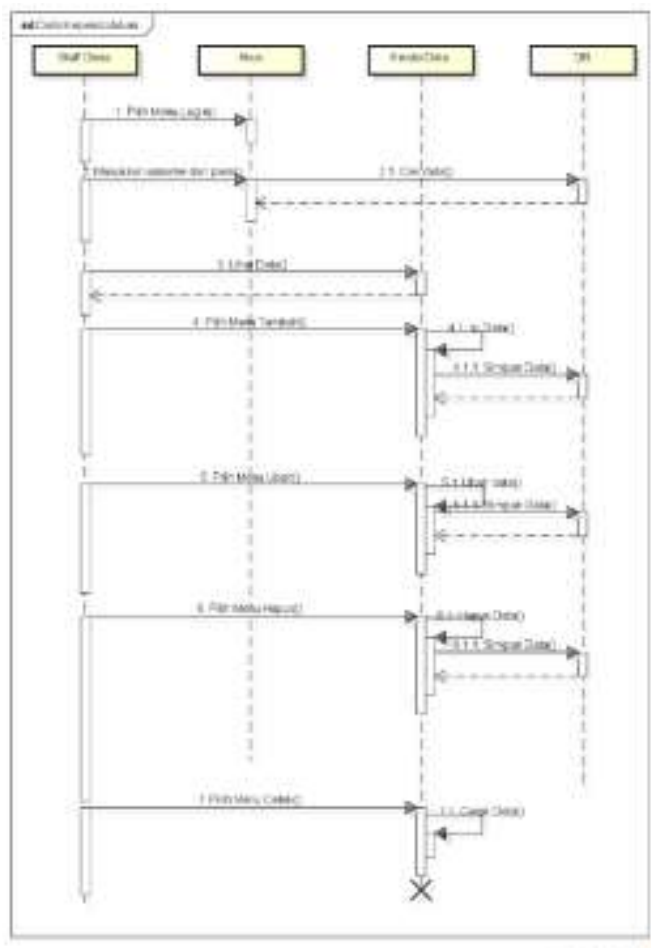

Gambar 6. Sequence Diagram Data Kependudukan

D. Design interface

Tampilan dari design interface yang akan dibuat yaitu:

1) Tampilan Utama

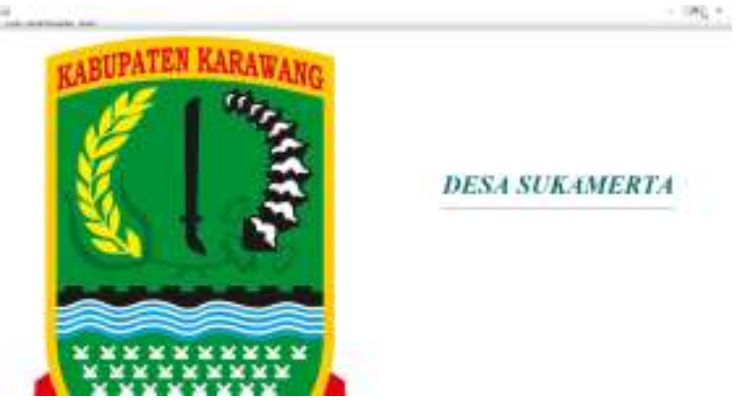

Gambar 7. Tampilan Utama

2) Login

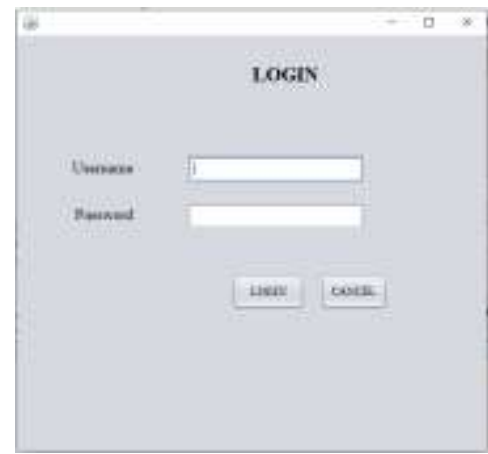

Gambar 8. Login 
3) Tampilan untuk Pembuaan Surat Pengantar KTP

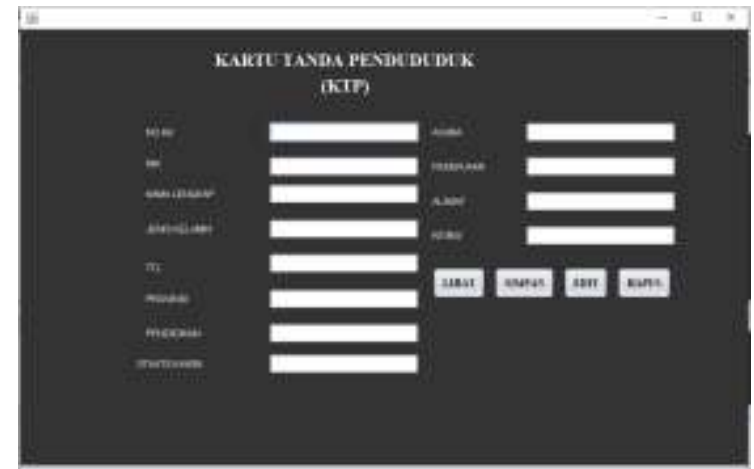

Gambar 9. Tampilan Surat Pengantar KTP

4) Tampilan untuk Pembuatan Surat Pengantar KK

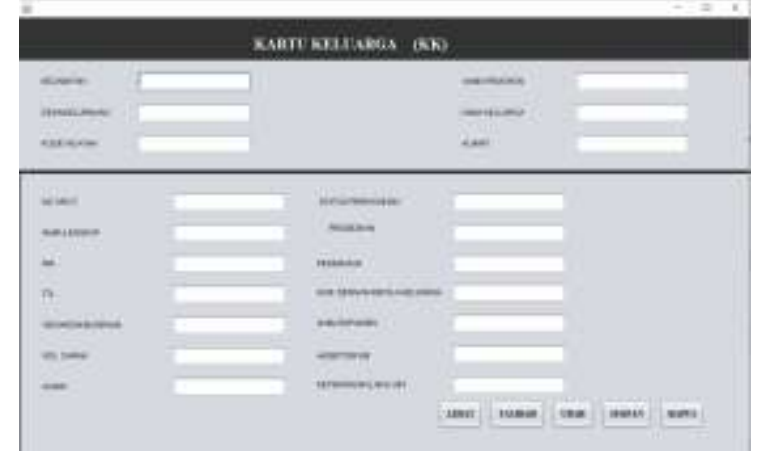

Gambar 10. Tampilan Surat Pengantar KK

\section{SIMPULAN DAN REKOMENDASI}

Berdasarkan pembahasan yang telah dipaparkan maka kesimpulan yang didapatkan "rancang bangun sistem administrasi kependudukan desa sukamerta berbasis desktop" yaitu bahwa dengan menerapkan metodologi SDLC dengan pemodelan UML untung perancangan sistem administrasi kependudukan dengan menggunakan tools netbeans 8.2 dengan interface atau tampilan yang telah dibuat yaitu pembuatan surat pengantar KK, KTP dan pendataan penduduk.

Sistem administrasi yang sudah dibuat dapat memudahkan perangkat desa dalam pembuatan surat pengantar dan pendataan kependudukan. Selain itu aplikasi ini sebagai sarana untuk pembuatan laporan setiap bulannya yang sudah terdata sebelumnya.

\section{DAFTAR PUSTAKA}

Dharmawan, W. S., Purwaningtias, D., \& Risdiansyah, D. (2018). Penerapan Metode SDLC Waterfall Dalam Perancangan Sistem Informasi Administrasi Keuangan Berbasis Desktop. JURNAL KHATULISTIWA INFORMATIKA, 5(2), 159-167.

Jannah, R., Masykur, F., \& Buntoro, G. A. (2019). RANCANG BANGUN SISTEM INFORMASI DATA KEPENDUDUKAN DESA BERBASIS DESKTOP DAN ANDROID. JURNAL ILMIAH MAHASISWA JURNAL ILMIAH MAHASISWA JURNAL ILMIAH MAHASISWA, 3(1), 68-74.

Kurniawan, R. C. (10(3)). INOVASI KUALITAS PELAYANAN PUBLIK PEMERINTAH DAERAH. Fiat Justisia Journal of Law, 569-586. 
Ina. (2020). Panduan Desa Sukamerta. Karawang.

Septiani, W. D. (2018). SISTEM INFORMASI PENGELOLAAN DATA PENDUDUK (STUDI SISTEM INFORMASI PENGELOLAAN DATA PENDUDUK (STUDI . JURNAL ILMU PENGETAHUAN JURNAL ILMU PENGETAHUAN, 23-28.

(2006). Undang-Undang Republik Indonesia Nomor 23 Tahun 2006 Tentang Administrasi Kependu Kependudukan:

Jakarta: https://www.dpr.go.id/dokjdih/document/uu/UU_2006_23.pdf.

Widya, M. A., Agustiawan, Y., Fibrian, I. D., \& Muttaqin, Z. (2016). Upaya Peningkatan Pelayanan Administrasi Kependudukan Menggunakan Teknologi Informasi: Rancang Bangun Sistem Informasi di Desa Sumbermulyo Kecamatan Jogoroto Kabupaten Jombang. Jurnal Ilmiah Teknologi Sistem Informasi, 2(2), 51-59. 